\title{
POROUS CONSTRUCTIONS OF WATER INTAKE STRUCTURES
}

\author{
${ }^{1}$ Progulny V., D.Sc., Professor, \\ varkadia@ukr.net, ORCID: 0000-0001-8310-3823 \\ ${ }^{1}$ Hurinchyk N., Ph.D., Associate Professor, \\ nagy@ukr.net, ORCID: 0000-0002-5009-1372 \\ ${ }^{1}$ Grachov I., Senior Lecturer, \\ giawork@ukr.net, ORCID: 0000-0002-4173-4452 \\ ${ }^{1}$ Borysenko K., Ph.D., Associate Professor, \\ nefertichevo@ukr.net, ORCID: 0000-0002-6179-6271 \\ ${ }^{1}$ Odessa State Academy of Civil Engineering and Architecture \\ 4, Didrikhson str., Odessa, 65029, Ukraine
}

\begin{abstract}
Water intake is an essential element of the water supply complex, normal operation of which depends on the quality of the water delivered to the consumer. Therefore, the water supply system should be effectively protected from various contaminants from the source, ice slurries, and juvenile fish.
\end{abstract}

The authors analyze the operation of existing coarse screen devices in channel water intakes; identify their main disadvantages, such as: mechanical jamming (clogging) of the screen holes with debris, leading to its failure and the need to replace, as well as the laborious cleaning and the high cost of screen materials. The article notes that during operation there is an increase in the pressure drop affecting the screen due to the accumulation of a large amount of contaminants on its surface, which could lead to a throughput and a significant amount of pollution.

To improve the quality of filtered water and operating conditions, the authors proposed to provide porous pipes installation instead of flat removable screens in the receiving section of the intake well. The material for their manufacture is a polymer concrete, based on crushed granite stones or gravel and a polymer binder - epoxy resin.

The article shows the scheme of intake well pipes installation, describes the principle of the proposed design, shows a graph obtained as a result of hydraulic calculation.

This design has a number of advantages over flat screens: automation of flushing, less clogging, greater throughput, lack of biofouling, high strength characteristics, low hydraulic resistance and durability. A porous polymer concrete-based structure, which is a pipe system that increases the reliability of water intakes, improves the quality of the water taken from the source and the conditions of operation, has been proposed.

The method of hydraulic calculation of porous pipes makes it possible to optimize their design parameters, to determine the diameter and pressure loss in them, which is very important when designing water intakes.

The aim of further research is to study the dynamics and degree of porous devices clogging by suspension at different concentrations in natural water.

Keywords: water intake structures, coarse screen, porous pipes, hydraulic calculation.

Introduction. In the conditions of surface water scarcity and the deterioration of water quality [1], one of the State's top priorities is to provide human settlements with high-quality drinking water. This requires improving water supply systems, increasing their efficiency and reliability through the application of the latest energy-saving technologies, materials and constructions in the complex of water-supply facilities. One of the most essential element of this complex is the water intake structures, on which the quality of the water delivered to the consumer and the economic indicators of the water supply scheme depend. 
The existing water intake structures do not always provide for their protective functions, as a result of which various contaminants, sore, ice slurries, juvenile fish, etc. enter the system. This, in turn, increases the mud load on the treatment facilities, reduces the efficiency of their operation, and impairs the quality of the treated water [2].

The intrusion of large quantities of fish, and especially of juvenile fish, into the water intake is highly damaging to natural fish resources. In addition, the fish caught in the water intake dies and rots, which creates an unacceptable sanitary and hygienic environment at the intake structures that provide water for household and drinking needs. Therefore, the water supply system must be effectively protected from various contaminants from the source, ice slurries, and juvenile fish.

Analysis of recent research and publications. Channel water intakes are widely used in the complex of water facilities. It consists of a water intake device, such as an intake head, which located directly in a river or canal, gravity lines or siphon lines that connect the intake head to the water intake mesh well, an onshore water intake well designed for rough mechanical water purification, and a pumping station of the first ascent [3].

Depending on the location of the onshore water intake well and the pumping station of the first ascent, there are two types of water intakes: separate and combined layout. "Separate layout" means that the pumping station is located in a detached building at some distance from the intake water well and is connected to it with suction pipelines (Fig. 1), and "combined layout" - the first ascent

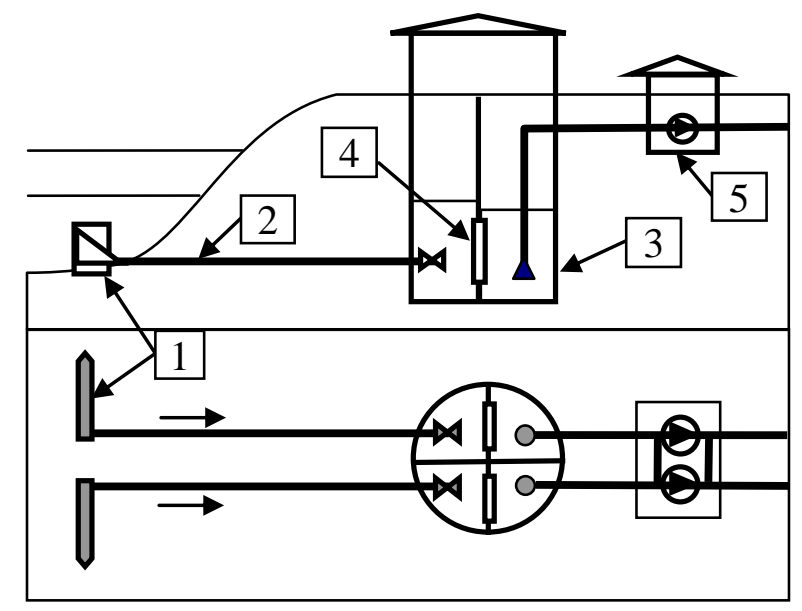

Fig. 1. Separate channel-type water intake scheme: 1 - intake head; 2 - gravity lines; 3 - onshore intake well; 4 - flat screens; 5 - first ascent pumping station pumping station and the water intake well are combined in one building.

An important element of the onshore intake well is the flat screen that installed in the partition between the receiving and the suction compartments. The screens largely determine the protective functions of water intake structures, as they are designed to contain sores, sediments, algae, leaves, etc., which can seriously hamper the operation of pumps, water supply and sewage treatment facilities. The flat screen has a cell size from $2 \times 2 \mathrm{~mm}$ to $5 \times 5 \mathrm{~mm}$ and is in the form of a wire sheet stretched on a steel frame, which is set in grooves located in the holes of

the partition.

The screen is flushed by reverse flow of water manually, for which it rises to the aboveground part of the well. Usually a spare one replaces the raised screen. Double grooves are arranged for the convenience of its replacement

Operational experience with channel water intakes of a separate type showed that the screens have a number of disadvantages [5]:

1. Mechanical jamming (clogging) of the screen through holes with sore, resulting in increased resistance and reduced throughput. This requires more frequent flushing of coarse screen.

2. The irreversible clogging of screens is particularly dangerous. Getting inside the cells, the contaminants are not flushed out by reverse flow of water, which leads to their failure and the need for replacement.

3. As a result of the accumulation of large amounts of pollution, the pressures affecting the screen are increasing, resulting a significant amount of contamination may break through.

4. To prevent screen corrosion, you must use expensive stainless materials.

5. The laborious washing the screens and cleaning them from shells. 
In order to reduce the pollution of nets, as well as one of the fish protection, special filtering cassettes are installed in the intake holes of water intakes: saturated or porous concrete on a cement binder [6]. The cassettes are a steel frame filled with incoherent filtering material (plastic balls, ceramist, gravel, rubble). The size of the fractions of the filter material is $10-25 \mathrm{~mm}$. This ensures the formation of pores sufficient for the free passage of water, but excludes the passage of fish. However, in this case, special measures are needed to protect the frame from corrosion, which makes the design more expensive.

The cassette can also be made in the form of blocks of porous concrete. The filler is also gravel or rubble with a large $10-20 \mathrm{~mm}$, and a high-mark binder cement. Blocks of porous concrete are inserted into the metal frame.

Biofouling poses a particular risk to porous cassettes, which also reduces their throughput [7-9]. Effective prevention of fouling is by pre-chlorination of water in front of the water collectors. However, it is known that chlorination can have a destructive effect on porous concrete cassettes. Chlorination also triggers justified protests by environmentalists due to the risk of entering the river. In recent years, the Department of Water Supply and Water Disposal of OSACEA (Odessa State Academy of Civil Engineering and Architecture) has been studying the possibility of using porous materials in the structures of water-supply facilities. As a result, a number of porous devices have been created, such as drainage distribution and drainage systems of filtration structures and facilities for pretreatment of water [10].

Goals and objectives. The objectives of this research are to improve the efficiency of water intake facilities, improve their operating conditions, and to extend the scope of application of porous polymer concrete structures that have proved to be effective in water treatment systems.

Materials and methods of research. In order to improve the quality of the filtered water and the operating conditions, the installation of porous pipes in the intake section of the well is provided instead of flat screens. The pipes are manufactured from porous polymer concrete, based on crushed granite or gravel with a size of 3-7 mm, a thickness of $30 \mathrm{~mm}$ and a binder - epoxy resin ED-16 or ED-20 with polyethylene polyamine hardener. The operating experience in the use of drainage distribution and discharge polymer concrete devices in filter structures for a long time (more than 40 years) has shown that they are not biofouled.

Figure 2 shows the installation of four porous polymer concrete pipes connected to the column for impulse flushing.
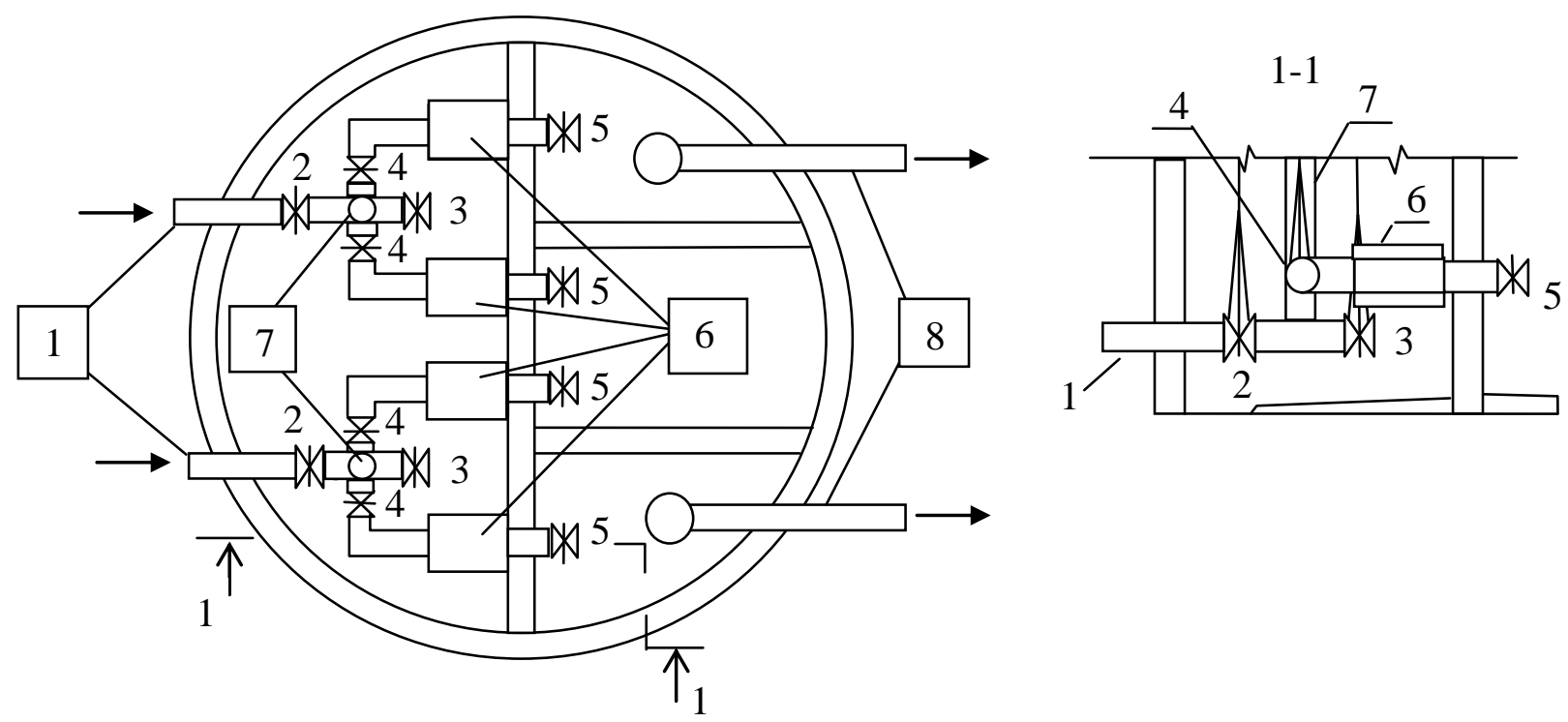

Fig. 2. Porous pipes instalation in the intake well:

1 - feed pipes; 2, 3, 4, 5 - gate valves; 6 - porous pipes; 7 - column for impulse flushing; 8 - suction lines 
The structure works as follows: water from the water supply source is delivered via the feed lines 1 to the intake section of the well (gate valves 2, 3, 5 are open). Then water passes through the porous pipes 6 and enters the intake section of the well, from where it is taken and supplied by the pumps of first lift to the treatment facilities. Flushing of porous pipes can be carried out both by reverse flow of water, and by impulse. For this, flushing water is supplied to column 7 (gate valves 4 are open and 2, 3, 5 are closed). Contaminants are flushed out into the intake section of the well, from where it is removed using an ejector.

Thus, flushing of porous pipes is reduced only to opening and closing the corresponding valves and can be carried out during flushing of the feed lines and the intake head. The proposed structure has a number of advantages over flat screens:

- flushing automation;

- less clogging;

- greater throughput;

- lack of biofouling;

- high strength characteristics;

- low hydraulic resistance;

- durability.

Results of research. According to the methodology developed at the Department of Water Supply and Water Disposal of OSACEA, a hydraulic calculation of porous pipes was made for channel water intakes of a separate type with a productivity of $0,2-1 \mathrm{~m}^{3}$ per second.

The calculation results are presented in the graph (Fig. 3), with the help of which it is possible to determine the diameter of the pipes, as well as the pressure losses in them depending on the productivity of the water intake.

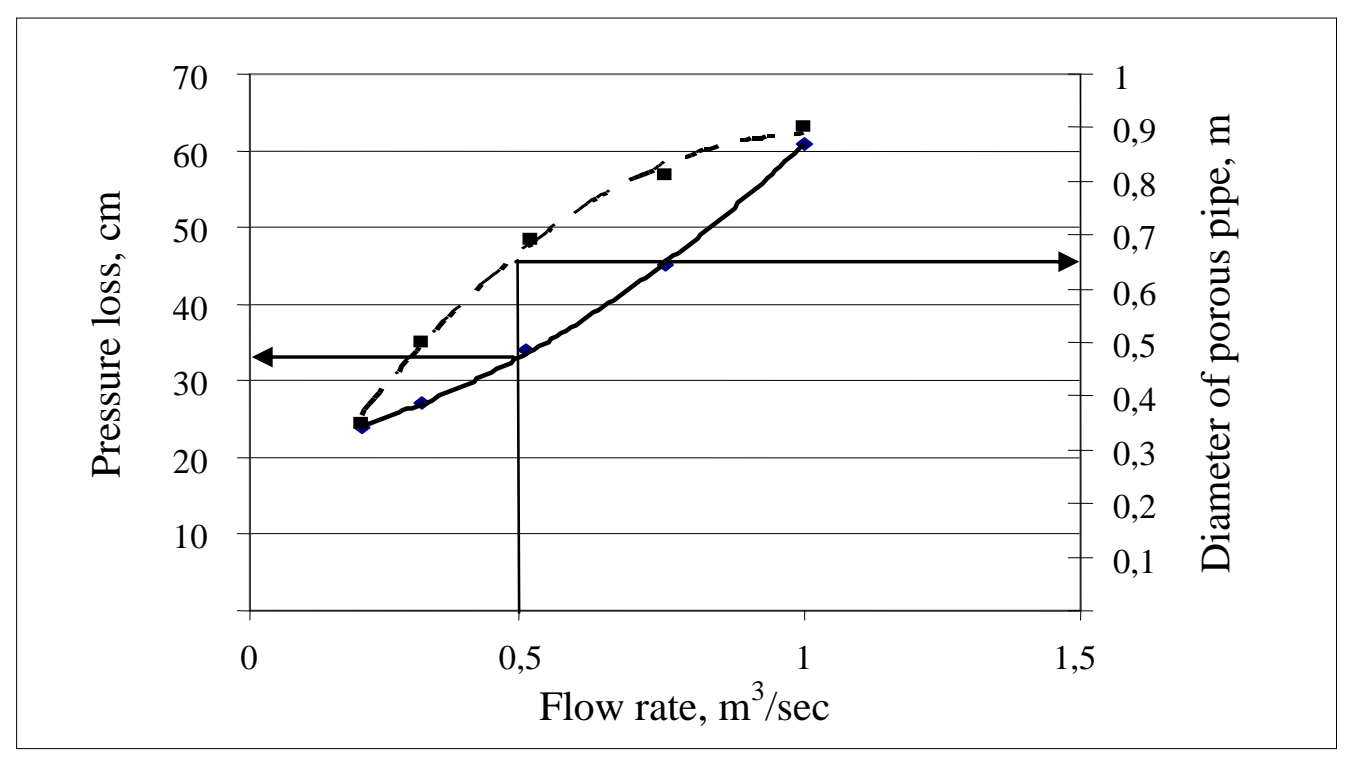

Fig. 3. The graph of pressure loss and diameter of porous pipes according to the flow rate:

- - - pressure loss;

- diameter of porous pipe.

So, for example, with a capacity of $0.5 \mathrm{~m}^{3} / \mathrm{s}$, the pressure loss in porous pipes will be $32 \mathrm{~cm}$ (when diameter is $0.65 \mathrm{~m}$ ). Thus, the proposed porous structures of water intake facilities make it possible to improve the reliability and efficiency of the facilities, the quality of the water extracted from the source and the operating conditions. The method of hydraulic calculation of porous pipes makes it possible to optimize their structural parameters, to determine the diameter and pressure loss in them, which is very important when designing water intakes. 
One of the main problem with the use of porous devices on water intake structures is their possible clogging with a suspension in natural water.

Earlier, at the Department of Water Supply and Water Disposal, researches were carried out on the clogging of porous polymer concrete with contaminated water [11], but such researches on natural water are relevant now.

Conclusion. The aim of further research is to study the dynamics and degree of clogging of porous devices with a suspension of various concentrations in natural water.

\section{References}

[1] Natsional'na dopovid' pro yakist' pytnoyi vody ta stan pytnoho vodopostachannya $\mathrm{v}$ Ukrayini: report. NUVHP. Rivne, 2013.

[2] A.K. Strelkov, "Zagryazneniye vodoyemov poverkhnostnym stokom", Vodosnabzheniye $i$ sanitarnaya tekhnika, M: AO «MosvodokanalNIIproyekt», no. 12, 25 p, 2015.

[3] A.M. Kurganov, Vodozabornyye sooruzheniya sistem kommunal'nogo vodosnabzheniya: uchebn. posob. M.; SPb.: Izdat. «ASV», 2001.

[4] U.M. Kuz'min, Setchatyye ustanovki sistem vodosnabzheniya: spravochnoye posobiye. L.: Stroyizdat, 1976.

[5] T.V. Kolesnikova, "Zashchita beregovykh vodozaborov ot popadaniya $\mathrm{v}$ nikh mekhanicheskikh vklyucheniy", Vestnik IrGTU, no. 1, pp. 168-171, 2014.

[6] V.V. Petrashkevich, "Razrabotka i obosnovaniye novykh rybozashchitnykh konstruktsiy meliorativnykh vodozaborov", avtoref. dis. na zdobuttya nauk. stupenya kand tekhn. nauk: 05.23.07, Vserossijskij nauchno-issledovatelskij institut gidrotehniki im. B.E. Vedeneeva, 2011.

[7] G.M. Matthews G.A. Swan, I.R. Smith, "Improved bypass and collection system for protection of juvenile salmon and steelhead trout at lower granite dam", Mar. Fish. Serv., no. 39:7, pp. 10-24, 2007.

[8] A.V. Anisimov "Sovershenstvovanie filtruuschig ribozaschitnix ustroystv promyshlennix I kommunalnix vodozaborov", avtoref. dis. na zdobuttya nauk. stupenya kand tekhn. nauk: 05.23.04, Penzenskij gosudarstvennyj universitet, 2002.

[9] I. Aksenova, "Wave response of enzymatic processes in biological systems of water treatment and treatment of precipitation", MATEC Web of Conferences, vol. 212, 03006, 2018. https://doi.org/10.1051/matecconf/201821203006.

[10] P.A. Grabovsky, V.I. Progul'nyy, G.M. Larkina, "Poristyy polimerbeton v konstruktsiyakh vodoprovodnykh sooruzheniy", Yenergoyefektivni tekhnologï $v$ mis'komu budívnitstvi ta gospodarství: mat-ly IV mezhd. nauch.-prakt. konf. Odesa, 2014, pp. 65-67.

[11] V. Progulny, M. Ryabkov, K. Borysenko, I. Grachov, "Theoretical and experemential study of mud injection porous drainage in filters with floating loading", TEHNICKKI GLASNIK, vol. 12, no. 4, pp. 231-235, 2018. 


\title{
ПОРИСТІ КОНСТРУКЦЇ̈ НА ВОДОЗАБІРНИХ СПОРУДАХ
}

\author{
${ }^{1}$ Прогульний В.Й., д.т.н., професор, \\ varkadia@ukr.net, ORCID: 0000-0001-8310-3823 \\ ${ }^{1}$ Гурінчик Н.О., к.т.н., доцент, \\ nagy@ukr.net, ORCID: 0000-0002-5009-1372 \\ ${ }^{1}$ Грачов I.А., ст. викладач, \\ giawork@ukr.net, ORCID: 0000-0002-4173-4452 \\ ${ }^{1}$ Борисенко К.I., К.т.Н., доцент, \\ nefertichevo@ukr.net, ORCID ID: 0000-0002-6179-6271 \\ ${ }^{1}$ Одеська державна академія будівництва та архітектури \\ вул. Дідріхсона, 4, м. Одеса, 65029, Україна
}

Анотація. Важливим елементом комплексу споруд водопостачання $\epsilon$ водозабірні споруди, від нормальної роботи яких залежить якість води, що подається споживачу, частина якої використовується на господарсько-питні потреби. Тому система водопостачання повинна бути ефективно захищена від попадання в неї різних забруднень із джерела, шуги, а також молоді риби.

Авторами наведено аналіз роботи існуючих сітчастих пристроїв в руслових водозаборах, виявлені основні їх недоліки, а саме - механічне заклинювання (кольматація) прохідних отворів сітки сміттям; незворотня кольматація сіток, яка веде до виходу їх з ладу і необхідності заміни; зростання перепаду тисків, що впливають на сітку в результаті накопичення великої кількості забруднень на іiї поверхні, через що можливий прорив сітки і миттєве забруднення води на водозабірних спорудах; трудомісткість очищення та промивки; дороговизна матеріалів для виготовлення сіток.

Для покращення якості проціджуваної води та умов експлуатації, авторами пропонується замість плоских знімних сіток в приймальному відділенні берегового колодязя передбачити встановлення пористих труб, виготовлених з полімербетона, виконаного на основі гранітного щебеню або гравію, та полімерного зв'язуючого - епоксидної смоли.

В статті показана схема установки системи труб в береговому колодязі, описаний принцип роботи запропонованої конструкції, наведено графік гідравлічного розрахунку пористих полімербетонних труб.

Ця конструкція має ряд переваг перед плоскими сітками: автоматизація промивки, менший ступінь кольматації, велика пропускна здатність, відсутність біообростання, високу міцність, низький гідравлічний опір, і довговічність.

Запропонована пориста конструкція на основі полімербетону, дозволяє підвищити надійність роботи водозабірних споруд, покращити якість води, що забирається $з$ джерела і спростити експлуатацію цих споруд, що є актуальним.

Методика гідравлічного розрахунку пористих труб дозволяє оптимізувати їх конструктивні параметри, визначати діаметр і втрати напору в них, що дуже важливо при проектуванні водозаборів.

Завданням для подальших досліджень є вивчення динаміки і ступеня кольматації пористих пристроїв зависсю різної концентрації присутньої в природній воді.

Ключові слова: водозабір, сітчасті пристрої, пористі труби, гідравлічний розрахунок. 


\title{
ПОРИСТЫЕ КОНСТРУКЦИИ НА ВОДОЗАБОРНЫХ СООРУЖЕНИЯХ
}

\author{
${ }^{1}$ Прогульный В.Й., д.т.н., профессор, \\ varkadia@ukr.net, ORCID: 0000-0001-8310-3823 \\ ${ }^{1}$ Гуринчик Н.А., к.т.н., доцент, \\ nagy@ukr.net, ORCID: 0000-0002-5009-1372 \\ ${ }^{1}$ Грачёв И.А., ст. преподаватель, \\ giawork@ukr.net, ORCID: 0000-0002-4173-4452 \\ ${ }^{1}$ Борисенко К.И., К.Т.Н., доцент, \\ nefertichevo@ukr.net, ORCID: 0000-0002-6179-6271 \\ ${ }^{1}$ Одесская государственная академия строительства и архитектуры \\ ул. Дидрихсона, 4, г. Одесса, 65029, Украина
}

Аннотация. Важнейшим элементом комплекса сооружений водоснабжения являются водозаборные сооружения, от нормальной работы которых зависит качество подаваемой воды потребителю. Поэтому система водоснабжения должна быть эффективно защищена от попадания в неё различных загрязнений из источника, шуги, а также молоди рыбы.

Авторами приведен анализ работы существующих сетчатых устройств в русловых водозаборах, выявлены основные их недостатки, а именно: механическое заклинивание (кольматация) проходных отверстий сетки сором, приводящая к выходу ее из строя и необходимости замены, а также трудоемкость очистки и дороговизна материалов для изготовления сеток. В статье отмечено, что в процессе эксплуатации происходит рост перепада давлений воздействующих на сетку из-за накопления большого количества загрязнений на ее поверхности, в результате чего может произойти прорыв и проскок значительного количества загрязнений,

Для улучшения качества процеживаемой воды и условий эксплуатации авторами предложено вместо плоских съемных сеток в приемном отделении берегового колодца предусмотреть установку пористых труб. Материалом для их изготовления служит полимербетон, выполненный на основе гранитного щебня или гравия и полимерного связующего - эпоксидной смолы.

В статье показана схема установки труб в береговом колодце, описан принцип работы предлагаемой конструкции, приведен график, полученный в результате гидравлического расчета.

Данная конструкция имеет ряд преимуществ перед плоскими сетками: автоматизация промывки, меньшая степень кольматации, большая пропускная способность, отсутствие биообрастания, высокие прочностные характеристики, низкое гидравлическое сопротивление, и долговечность.

Предложенная пористая конструкция на основе полимербетона, позволяет повысить надёжность работы водозаборных сооружений, улучшить качество забираемой воды из источника и упростить их эксплуатацию.

Методика гидравлического расчета пористых труб позволяет оптимизировать их конструктивные параметры, определять диаметр и потери напора в них, что очень важно при проектировании водозаборов.

Задачей дальнейших исследований является изучение динамики и степени кольматации пористых устройств взвесью различной концентрации, находящейся в природной воде.

Ключевые слова: водозабор, сетчатые устройства, пористые трубы, гидравлический расчет.

Стаття надійшла до редакції 08.10.2020

Bulletin of Odessa State Academy of Civil Engineering and Architecture, 2020, no. 81, page 149-155 